\title{
Pond fish culture and needs for credit: A study in selected areas of Tangail district
}

\author{
M. A. Rahman*, F. Ahmed, M. S. Islam ${ }^{1}$ and M. A. Khan \\ Department of Agricultural Finance, Bangladesh Agricultural University, Mymensingh-2202 and ${ }^{1}$ Ministry of Fisheries \\ and Livestock, Bangladesh, ${ }^{\star} E-m a i l:$ marahman@bau.edu.bd
}

\begin{abstract}
This study examines the cost, returns, profitability of pond fish farm, requirements, adequacy, sources and utilization patterns of credit and problems associated with pond fish farming in Madhupur Upazila of Tangail district. A total of 60 farmers with small traditional types of ponds were randomly selected for this study. Both description and econometric analysis were used. Human labour was the most important and one of the largest inputs used for pond fish production. The average per acre human labour cost, fingerlings cost, feed cost, chemical fertilizers cost, manure cost, and lime cost were Tk. 9345, Tk. 18506, Tk.10476, Tk.3759, Tk. 329, and Tk.1605, respectively. Pond rental value was calculated at Tk. 11537 per acre for one year which shared 26.42 percent of total costs of pond fish production. Gross return was Tk. 70928 per acre. Gross margin and net return of the pond fish farm were Tk.38118 and Tk. 24081 per acre respectively. The BCR was 1.514 . Out of 60 farmers, only 11 farmers received loans from different sources and 86.67 percent of applied amount received. About 83 percent of the loan used for operating expenditure of farming and rest 17 percent loan used for non-farm expenditure. There were some problems in fish farming, such as insufficient water, high feed cost etc. Government needs to provide subsidized feed, technical supports and credit facilities for the small scale fish farmers.
\end{abstract}

Keywords: Pond fish farming, Cost and Return, Profitability, Credit

\section{Introduction}

Fisheries is one of the major sub-sector in the agricultural sectors and plays a vital role in the socioeconomic development of rural area, fulfilling the animal protein demand, creating employment opportunity, alleviating poverty and earning foreign exchange for the country. About 1.2 million people are directly employed in this sector and another 12 million people indirectly earn their livelihood out of activity related to fisheries (Islam, 2010). The fisheries sector contributes $4.64 \%$ of the gross domestic product (GDP), 18.43\% of agricultural GDP (BBS, 2011). Total inland fish production is 2381916 metric ton; total marine fish production is 517287 metric ton (BBS, 2011). Bangladesh situated in the north eastern part of the South Asian subcontinent. The country is blessed with about 4.047 million ha open inland water body, 0.528 million ha closed inland water body and marine water covers an area of 0.166 million ha. These water bodies are very rich in fisheries resources. Bangladesh has at least 260 freshwater fish species and over 475 marine species (DoF, 2009). Almost all Bangladeshi people rely on a wide variety of fish species to meet their protein needs. Fish supplies a valuable source of protein calcium, mineral, fatty acids, vitamins and oil containing poly-unsaturated fatty acids. Fish production could be expected to play an important role in supplying sufficient fish. Increased pond fish production in Bangladesh can help to meet the increased domestic demand. In order to meet the shortage of fish, the Department of Fisheries (DoF) and some non-government organizations (NGOs) are encouraging people to increase fish production in their surrounding water areas, such as pond, haor, baor, beel, etc. Generally, profitable pond fish production depends on the application of its inputs management and technologies etc. At present, some of the fish producers in our country understood the positive effect of scientific aquaculture and they already adopted a number of improved technologies for increasing fish production through pond fish culture. But most of them are facing acute problem of financing.

Increasing productivity of pond fish in a sustainable agricultural credit is a howling need of the nation to cater to the growing demand for the fish of the increasing population. The present study provides valuable information about pond fish culture, credit availability and utilization patterns. The results of analysis provide information about the cost and return of pond fish farming and credit requirements. It also indicates the inputs that provide relatively higher returns to total output. The information will be helpful to 
the policy makers and the prospective producers in making decision on pond fish production. The result of the study also provides valuable information to the researchers who are interested to conduct similar type of research in future. So, the researcher attempts to undertake the study with the following objectives:

(i) To identify the socioeconomic characteristics of the sample respondents;

(ii) To estimate the cost, returns and profitability of pond fish culture in the study area;

(iii) To assess the requirements, adequacy, sources and utilization patterns of credit; and

(iv) To identify the nature of problems associated with pond fish culture.

\section{Materials and Methods}

A sample of 60 pond fish farmers were selected randomly from Laufula, Bondarail, Chaparkona, Arailbari, Aralia, Gopath, Gaingair, Sivrambari, Kalamajee village under Madhupur Upazila of Tangail District. Primary data were collected personally from respondents through a sample survey with the help of a structured and pre-tested interview schedule. Focus group discussion and observation techniques were also used to get relevant information. The data and information were collected during the period from September to December 2012. A stratified random sampling technique was followed in this study. Simple statistical techniques such as percentage and arithmetic mean or average were employed to analyze the data. Activity budgets were calculated.

Activity budgets (Dillon and Hardaker, 1993) of the pond fish culture were prepared using the following algebraic equation:

$$
\begin{aligned}
\pi & =P_{y} Y-\sum_{i=1}^{n}\left(P_{x i} X\right)-T F C \\
\pi & =\text { Net return (Tk./acre); } \\
P_{y} & =\text { per unit price of the product }(T k . / k g) ; \\
Y & =\text { Quantity of the production per acre }(\mathrm{Kg}) ; \\
P_{x i} & =\text { Per unit price of } i^{\text {th }} \text { inputs (Tk.); } \\
X_{i} & =\text { Quantity of the } \mathrm{i}^{\text {th }} \text { inputs per acre }(\mathrm{kg}) ; \\
T F C & =\text { Total fixed cost (Tk.); } \\
\mathrm{i} & =1,2,3 \ldots \ldots \ldots \ldots \ldots \ldots . ., \mathrm{n} \text { (number of inputs). }
\end{aligned}
$$

Apart from the profitability analysis, undiscounted benefit-cost ratio (BCR) was calculated dividing per hectare gross return by gross cost.

\section{Results and Discussion}

\section{Income level of the respondents}

Income level was one of the many variables to measure the socio-economic status of a household. Table 1 reveals that $8.33 \%$ of the farmers were included in annual income level of Tk. $25000-75000,11.67 \%$ of farmers were Tk.75001-100000, 25\% of farmers were Tk.100001-150000, $16.67 \%$ of farmers were Tk. $150001-200000,6.67 \%$ of farmers were Tk. $200001-250000,15 \%$ of farmers were Tk.250001-350000 and $16.67 \%$ of farmers were above Tk. 350000 .

Table 1. Level of income of the respondents

\begin{tabular}{|c|c|c|}
\hline Income Range & Number of respondents & Percentage \\
\hline $25000-75000$ & 05 & 11.33 \\
\hline $75001-100000$ & 07 & 25 \\
\hline $100001-150000$ & 15 & 16.67 \\
\hline $150001-200000$ & 10 & 6.67 \\
\hline $200001-250000$ & 04 & 15 \\
\hline $250001-350000$ & 09 & 16.67 \\
\hline Above 350000 & 10 & 100 \\
\hline Total & 60 & 0 \\
\hline
\end{tabular}

Source: Field survey.2012 


\section{Age distribution}

In this study, the pond fish farmers were classified into three age groups such as 20-40 years, 41-60 years and above 60 years. Age classification of sample pond fish farmers was presented in Table 2 . It was found that $61.67 \%$ of the respondents belonged to the age group of $20-40$ years. About $28.33 \%$ of the respondents were age group of 41-60 years and rest $10 \%$ of the respondents were age group of above 60 years. This information implies that the majority of the sample farmers were in active age group of 20-40 years indicating that they provided more physical efforts for fish farming.

Table 2. Age distribution of sample farmers

\begin{tabular}{|l|c|c|}
\hline Age group (years) & Number & Percentage \\
\hline $20-40$ & 37 & 61.67 \\
\hline $41-60$ & 17 & 28.33 \\
\hline Above 60 & 06 & 10 \\
\hline Total & 60 & 100 \\
\hline
\end{tabular}

Source: Field Survey, 2012

\section{Participation of male and female}

A total 60 (Male 48 and Female 12) farmers were involved in the fish farming in the study area. That means $80 \%$ are male and $20 \%$ are female were involved in the fish farming in the study area (Table 3 ).

Table 3. Existence of Male and female fish producers in the study area

\begin{tabular}{|l|c|c|}
\hline \multirow{2}{*}{ Sex } & \multicolumn{2}{|c|}{ Number of pond fish producers } \\
\cline { 2 - 3 } & No. & Percentage \\
\hline Male & 48 & 80 \\
\hline Female & 12 & 20 \\
\hline Total & 60 & 100 \\
\hline
\end{tabular}

Source: Field survey, 2012

\section{Level of education}

Information on the education levels of the respondents is presented in table 4 . It is observed from table 4 that $16.67 \%$ of pond fish producers did not have any formal education, $28.33 \%$ had primary level, $40 \%$ had S.S.C. level; $11.67 \%$ had H.S.C. level $3.33 \%$ had graduation and above level of education in the study areas. Overall fish farmers in general were literate persons.

Table 4. Educational status of sample respondents

\begin{tabular}{|l|c|c|}
\hline Level of education & Number of respondents & \% of total respondent \\
\hline Illiterate & 10 & 16.67 \\
\hline Primary & 17 & 28.33 \\
\hline S.S.C & 24 & 40 \\
\hline H.S.C & 7 & 11.67 \\
\hline Graduate and above & 2 & 3.33 \\
\hline Total & 60 & 100 \\
\hline
\end{tabular}

Source: Field Survey, 2012

\section{Occupation of the fish farmers}

The pond fish owners were engaged in various types of occupation. The main occupation of farm family considered in the present study was the occupation from which most of the income was earned. The occupations of fishpond owners are presented in Table 5. It appears that farming, business, service, fish farming and others represented main occupation for $65 \%, 6.67 \%, 5 \%, 21.67 \%, 1.67 \%$ respectively of the pond fish farmers. On the other hand, $23.33 \%, 11.67 \%, 1.67 \%, 6.67 \%, 41.67 \%, 15 \%$ of the total fishpond owners had farming, business, service, day labour, fish farming and others are respectively as their subsidiary occupation. 
Table 5. Distribution of sample pond fish farmers by types of occupation

\begin{tabular}{|c|c|c|}
\hline \multicolumn{2}{|c|}{ Number } & Percentage \\
\hline Main & 39 & 65 \\
\hline Farming & 4 & 5.67 \\
\hline Business & 3 & 21.67 \\
\hline Service & 13 & 1.67 \\
\hline Fish farming & 1 & 100 \\
\hline Others & 60 & 23.33 \\
\hline All groups & & 11.67 \\
\hline Subsidiary & 14 & 1.67 \\
\hline Farming & 7 & 6.67 \\
\hline Susiness & 1 & 41.67 \\
\hline Day labour & 4 & 15 \\
\hline Fish farming & 25 & 100 \\
\hline Others & 9 & \\
\hline All groups & 60 & \\
\hline
\end{tabular}

Source: Field Survey, 2012

\section{Distribution of sample ponds according to size}

Pond size may vary in different locations on the basis of physical and socioeconomic conditions. A suitable pond size was required to minimize the production cost and maximize the production. Table 6 shows distribution of areas of the $85 \%$ of pond fish farms were from 0.05 to 0.5 acres. There are no fish ponds occupying below 0.05 acres to above 5 acres.

Table 6. Distribution of sample ponds according to size

\begin{tabular}{|l|c|c|}
\hline \multirow{2}{*}{ Size of pond (acre) } & \multicolumn{2}{|c|}{ Pond fish producers } \\
\cline { 2 - 3 } & Number & Percentage \\
\hline $0.05-0.5$ & 51 & 85 \\
\hline $0.51-1$ & 7 & 11.67 \\
\hline $1.01-5$ & 2 & 3.33 \\
\hline
\end{tabular}

Source: Field Survey, 2012

\section{Estimation of costs and returns}

Cost and returns were calculated from farmer's point of view. Costs were calculated for all the family supplied and purchased inputs used in producing pond fish. The market prices of inputs and output were used.The cost of pond fish production included the costs of human labour and material input (feed, fertilizer, manure and fingerlings), land use cost and cost on operating capital. The items have been described below:

Cost of human labour: Human labour was required in different operations and managements, such as reconstruction, feed application, fertilizer application, compost making and its application, application of cow dung, Stocking of fingerlings, making feeding ring, weeding and fish harvesting and marketing. Both family and hired labour were used in the pond fish culture. Family labour included the farm operator himself/ herself and other members of his family i.e., brothers and children etc. Labour was measured in terms of man-day which usually consisted of 8 hours. For women and children, man equivalent hours were estimated. This was computed by converting all women and children hours into man-equivalent hours assuming 1 adult male $=1.5$ women $=2$ children. The average human labour cost per acre was Tk. 9345.

Cost of fingerlings: Per unit price of fingerlings depends on their sizes $s$ well as the concerned fish species. The stocking rate of fingerlings varies with the fertility of pond. Pond fish farmers in the study area used purchased fingerlings and the cost was calculated on the basis of farm-gate price. The selected species of fingerlings were Rui, Catla, Mrigal, karfu, Silver carp, Grass carp, Mirror carp, Shrimp, Chetol, Tilapia, Pangus, Kalabous and Sharpunti used for fish culture. The average unit price of fingerlings was 3Tk. /piece. The purchasing cost of fingerlings per acre for pond fish production was Tk. 18506. 
Cost of feed: It was found that almost all the farmers applied supplementary feed such as both rice-bran and oil-cake. It varied according to the intensity of cultivation. Farmers normally do not use pellet feed because it is costly and not available. In the study area, farmers applied rice bran $503 \mathrm{~kg}$ per acre and oil cake $148 \mathrm{~kg}$ per acre. Rice bran costs Tk. 6031 per acre and oil-cake costs Tk. 4434 per acre. The average feed cost per acre was Tk.10476.

Cost of fertilizers: Fertilizer was generally used in the fishpond to create condition, which facilitates an increase in production of good quality natural fish feed, thereby increasing fish production. Farmers used three kinds of chemical fertilizers namely, Urea, Triple super phosphate (TSP) and Manure in the study area. The cost of fertilizer was charged at the prevailing market rate in the study area during pond fish culture season. Farmers applied Urea $122 \mathrm{~kg}$ per acre and TSP $51 \mathrm{~kg}$ per acre. Urea and TSP costs were Tk. 1467 and Tk. 2291 per acre, respectively. The average fertilizer cost per acre was Tk.3759. Manure was important for fish production. It was observed that, farmers used cow-dung in fish ponds as manure in the study area. Cow-dung was home supplied and purchased. The cost of cow-dung was calculated Tk.0.50/kg. It observed that farmers used $657 \mathrm{~kg}$ manure per acre per year. So, the average cost of manure per acre was Tk. 329.

Cost of lime: Lime application was an important factor for pond fish pond production. Lime was used mainly to neutralize acidity in the soil and water of pond. Lime assists in release of nutrient from the soil and promotes the bacterial breakdown of water material including green manure. The average quantity of lime used by fish farmers was $115 \mathrm{~kg} /$ acre per year. Average cost incurred for lime was Tk.1605 (Table 7).

Table 7. Per acre material inputs costs for fish farmers

\begin{tabular}{|l|c|c|c|c|}
\hline Items of cost & Quantity $(\mathrm{Kg})$ & Price/Kg & Total cost (Tk.) & \% of total cost \\
\hline Feed & & & & 6036 \\
\hline Rice bran & 503 & 12 & 4440 & 37.32 \\
\hline Oil cake & 148 & 30 & & 27.45 \\
\hline Fertilizer & & & 1464 & 9.05 \\
\hline Urea & 122 & 12 & 2295 & 14.19 \\
\hline TSP & 51 & 45 & 329 & 2.03 \\
\hline Manure & 657 & 0.5 & & \\
\hline Chemical Cost & & 14 & 1610 & 9.95 \\
\hline Lime & 115 & & 161734 & 100 \\
\hline Total & & & & \\
\hline
\end{tabular}

Source: Field Survey, 2012

Land use cost: Lease value of pond was consisted as land use cost. It was calculated at the rate of prevailing cash rental value of per acre pond land in the study area. Pond rental value was calculated at Tk. 11537 per acre for one year which shared 26.42 percent of total costs of pond fish production. This was treated as fixed cost in this study.

Cost on operating capital (IOC): Interest on operating capital was calculated by taking into account the costs incurred on all field operations but excluding those items for those interest was already been calculated. On an average, the cost was estimated at Tk. 7349.67. It constituted 5.34 percent of gross costs (Table 8).

Table 8. Average gross costs of pond fish

\begin{tabular}{|l|l|l|}
\hline \multicolumn{1}{|c|}{ Cost items } & Cost (Tk/acre) & Percentage \\
\hline Variable cost & & 19.95 \\
\hline Human labour & 9345 & 14.09 \\
\hline Fingerlings & 6605 & 22.36 \\
\hline Feed & 10476 & 8.02 \\
\hline Fertilizer & 3759 & 0.70 \\
\hline Manure & 329 & 3.44 \\
\hline Lime & 1610 & 1.46 \\
\hline Electricity cost & 686 & \\
\hline Fixed cost & & 24.63 \\
\hline Land use cost & 11537 & 5.34 \\
\hline Interest on operating capital & 2500 & 100 \\
\hline Total & 46847 & \\
\hline
\end{tabular}

Source: Field Survey, 2012 


\section{Gross Return}

Gross return was the value of fish produced in money terms. This was calculated by multiplying the total amount of production by their respective market prices. Gross return from pond fish production was estimated at Tk. 70928 (Table 9).

Table 9. Average returns from pond fish production per acre per year

\begin{tabular}{|c|c|c|c|c|}
\hline Yield & Quantity (Kg) & Price/Kg & Value (Tk.) & Percentage \\
\hline Gift and consumption & 29 & 143 & 4147 & 5.85 \\
\hline Sale & 467 & 143 & 66781 & 94.15 \\
\hline Total & 496 & 143 & 70928 & 100 \\
\hline
\end{tabular}

Source: Field Survey, 2012

\section{Gross Margin}

Producers generally want to gain maximum return over variable cost of production. Gross margin was the difference between the gross return and total variable cost. The gross margin of pond fish production was estimated at Tk. 38118 (Table 10).

\section{Net Return}

Per acre net returns from pond fish production was calculated by deducting gross costs from gross returns. It can be noted from (Table 10) that per acre net return was Tk.24081.

Table 10. Per acre Costs and Economic Returns of Pond Fish

\begin{tabular}{|l|c|}
\hline \multicolumn{1}{|c|}{ Particulars } & Cost and Economic Returns(Tk./acre) \\
\hline Yield (Y) kg & 496 \\
\hline Gross Return (GR) Tk. & 70928 \\
\hline Total variable cost (TVC) TK. & 32810 \\
\hline Total fixed cost (TFC) Tk. & 14037 \\
\hline Total cost/Gross cost TC=(TVC+TFC) Tk. & 46847 \\
\hline Gross Margin GM= (GR-TVC) Tk. & 38118 \\
\hline Net Return NR=(GR-TC) Tk. & 24081 \\
\hline Return over per Tk. investment (NR/TC) & 0.51 \\
\hline BCR (GR/TC) & 1.51 \\
\hline
\end{tabular}

Source: Field Survey, 2012

\section{Return over per taka investment}

Net return per taka invested was the ratio between net return and total cost. Table 10 shows that net return per taka investment in pond fish farming was 0.514 . It means that by spending Tk.100 net return of Tk. 51 was obtained.

\section{Benefit cost Ratio (BCR)}

Benefit cost ratio for pond fish culture was determined as ratio of gross return to gross cost. Table 10 reveals that benefit cost ratio (undiscounted) of pond fish farming was 1.51 indicating that production of pond fish was profitable. The finding justifies that benefit cost ratio was higher than one, Suggesting that there was a potential for pond development in study area.

\section{Requirements, adequacy, sources and utilization patterns of credit}

The farmers of Taingal district are not so solvent. Although they do not want to take loan easily, they somehow try to manage continue farming without taking loan. Eleven farmers among 60 took loan from different sources (Table 11).

Table 11. Sources of received loans

\begin{tabular}{|l|c|c|}
\hline \multicolumn{1}{|c|}{ Sources } & Number of respondents & Percentage \\
\hline Grameen Bank & 02 & 18.18 \\
\hline Bangladesh Krishi Bank & 04 & 36.36 \\
\hline Mahajan & 02 & 18.18 \\
\hline Relatives & 02 & 18.18 \\
\hline Friends & 01 & 9.09 \\
\hline Total & 11 & 100 \\
\hline
\end{tabular}

Source: Field Survey, 2012 
Table 12 shows that the farmers who applied loan amount between Tk. 2000-Tk. 5000 received almost $50 \%$ of the applied amount. The farmers who applied Tk. 5001 - Tk. 8000 and Tk. 8001-Tk. 1200 received $100 \%$ of the applied amount.

Table 12. Amount of loan applied for and loan received by the borrower farmers

\begin{tabular}{|c|c|c|c|c|}
\hline $\begin{array}{c}\text { Farmers category } \\
\text { according to loan size }\end{array}$ & $\begin{array}{c}\text { Number of } \\
\text { respondents }\end{array}$ & $\begin{array}{c}\text { Total amount } \\
\text { applied for (Tk.) }\end{array}$ & $\begin{array}{c}\text { Average Amount } \\
\text { received(Tk.) }\end{array}$ & $\begin{array}{c}\text { Amount } \\
\% \text { of amount applied }\end{array}$ \\
\hline Tk.2000-Tk.5000 & 05 & 20000 & 10000 & 50 \\
\hline Tk.5001-Tk.8000 & 02 & 15000 & 15000 & 100 \\
\hline Tk.8001-Tk.12000 & 04 & 40000 & 40000 & 100 \\
\hline Total & $\mathbf{1 1}$ & $\mathbf{7 5 0 0 0}$ & $\mathbf{6 5 0 0 0}$ & $\mathbf{8 6 . 6 7}$ \\
\hline
\end{tabular}

Source: Field Survey, 2012

Credit plays an important role in farm business. Many people cannot start a business without taking loan. It helps people to be self employed. It increases farm productivity and income if it properly utilized. So, the pattern of credit utilization is very important in farming. To make profit, bank or NGO must ensure that the borrowed funds are used for productive purposes. Proper use of credit promotes increased production and benefits the borrowers involved. Use of credit for unproductive purposes very often results in overdue of loans and weakens the financial viability of the concerned financial institution. Table 13 shows the pattern of utilization of their loan money.

Table 13. Percentage of utilization of loan in different purposes

\begin{tabular}{|c|c|c|c|c|}
\hline \multirow[t]{2}{*}{ Item of expenditure } & \multicolumn{4}{|c|}{ Percentage amount of loan used(Tk.) } \\
\hline & $\begin{array}{l}\text { Loan amount } \\
(2000-5000)\end{array}$ & $\begin{array}{c}\text { Loan amount } \\
(5001-8000)\end{array}$ & $\begin{array}{l}\text { Loan amount } \\
\text { (8001-12000) }\end{array}$ & All \\
\hline \multicolumn{5}{|l|}{ A. Capital expenditure } \\
\hline i) Pond excavation & 10.18 & 10.90 & 10.00 & 10.36 \\
\hline ii) Pond re-excavation & 5.00 & 2.05 & 10.65 & 5.9 \\
\hline \multicolumn{5}{|l|}{ B. Operating expenditure } \\
\hline i) purchase of fingerlings & 23.81 & 28.47 & 17.49 & 23.26 \\
\hline ii) Purchase of fertilizer & 32.65 & 29.05 & 31.93 & 31.21 \\
\hline iii)Purchase of feed & 2.19 & 25.16 & 10.14 & 12.50 \\
\hline Total operating expenditure of farming & 73.83 & 95.63 & 80.21 & 83.23 \\
\hline \multicolumn{5}{|l|}{ C. Non-farm expenditure } \\
\hline i) Purchase of food & 20.03 & - & 4.97 & 8.33 \\
\hline ii) Investment in business & 6.14 & 1.44 & 3.38 & 3.65 \\
\hline iii)Repayment of old debt & - & 2.93 & 11.44 & 4.79 \\
\hline Total non-farm expenditure & \multicolumn{2}{|l|}{26.17} & \multirow{2}{*}{$\begin{array}{c}19.79 \\
100\end{array}$} & 16.77 \\
\hline Grand total & 100 & 100 & & 100 \\
\hline
\end{tabular}

Source: Field Survey, 2012

\section{Problems and constraints of pond fish culture}

Water is essential for pond fish culture. Bangladesh belongs to the monsoon region that represents sufficient water was in the monsoon season but insufficient water was in the dry season. Table 14 reveals that $23.33 \%$ of the pond fish farmers complained the insufficient water as the problem, $80 \%$ of the respondents claimed that diseases of the fish was the major problem in pond fish culture. Agricultural extension workers and Upazila Fisheries Officers can help the farmers for solving this problem. High feed cost was the main problem of the respondents. As a result of high feed cost, farmers' cost of production was increased and profitability decreased. Table 14 also shows that most $(91.67 \%)$ of the respondents claimed high feed cost as their big problem. Government should take appropriate policies to overcome this problem. Predators were another minor problem in the selected area. Only $3.33 \%$ of the respondents claimed predators as the fourth problem (Table 14). About $7 \%$ of the respondents claimed theft as a problem where 'Night Guard' was not available. Sometimes neighboured were doing that job just for enemies. Table 14 shows that $63.33 \%$ of the respondents claimed unexplained mortality of fish as their major problem due to lack of proper knowledge on the relevant technology. Farmers were not able to find 
the causes of mortality of the fish. Fisheries expert could help to solve this problem. The lack of fingerlings was found as another problem for the farmers. About $18.33 \%$ of the respondents claimed nonavailability of seed fish as their problem. Fingerlings are the most important material input in pond fish culture method. But proper stocking size is not always available in the culture time because of lack of fingerlings nursery in Bangladesh. Government, private organisation and Non Government Organisations could establish new nurseries to solve this problem. Higher demand for labour was another problem for $11.67 \%$ of the respondents especially in the harvesting period. This problem could be solved by exchanging their labour with other farmers. Higher costs in general were another major problem in pond fish culture technology. Farmers need more operating capital specially to buy fingerlings. About one third of the respondents complained higher cost as a major problem. In the pond fish culture, technology is needed to prepare pond excavation. Normally, pond excavation takes a proportion of the total costs of the pond fish culture. Nearly $70 \%$ of the respondents claimed higher cost of pond excavation for pond fish culture as their problem.

Table 14. Constraints of pond fish culture as ranked by farmers (Percentages are in parentheses)

\begin{tabular}{|l|c|c|c|c|c|}
\hline \multirow{2}{*}{\multicolumn{1}{c|}{ Problem }} & \multicolumn{5}{|c|}{ Number of times problem was ranked } \\
\cline { 2 - 6 } & First & Second & Third & Fourth & Total $(\mathrm{n}=60)$ \\
\hline Insufficient water & 04 & 02 & 05 & 03 & $14(23.33)$ \\
\hline Diseases & 13 & 14 & 11 & 10 & $48(80)$ \\
\hline High feed cost & 24 & 15 & 10 & 06 & $55(91.67)$ \\
\hline Predators & 00 & 00 & 00 & 02 & $02(3.33)$ \\
\hline Theft & 00 & 00 & 02 & 02 & $04(6.67)$ \\
\hline Unexplained mortalities & 10 & 16 & 07 & 05 & $38(63.33)$ \\
\hline Non availability of seed fish & 00 & 00 & 04 & 07 & $11(18.33)$ \\
\hline High labour demand & 00 & 00 & 02 & 05 & $07(11.67)$ \\
\hline High costs in general & 03 & 04 & 07 & 06 & $20(33.33)$ \\
\hline High cost of pond excavation & 06 & 09 & 12 & 14 & $41(69.01)$ \\
\hline
\end{tabular}

Source: Field Survey, 2012

\section{Conclusion}

Fisheries are an extensive economic activity in Bangladesh. Fish constitutes a common item of the diet of the population and a major source of protein supply. The bulk of the fish catches comes from inland fishery resources of which ponds constitute an important source. In most of the ponds, fish culture is practiced mostly by traditional ways. The government of Bangladesh is disbursing a considerable amount of credit each year for development of pond fish culture through proper management. The cereal crops can satisfy hunger temporarily, but can hardly fulfill the nutritional requirements which are most essential for human body. But the present level of animal protein production in Bangladesh fails to satisfy the demand of increasing population. For increasing the production of fish, it is obvious that number of fish must be increased. Credit can play important roles of pond fish farming but all farmers were not interested to borrow money from different financial institutions. There were some problems in the study area in pond fish farming, such as insufficient water, diseases, theft, high feed cost etc. Most of the producers face these problems. Therefore the findings suggested that in order to increase area under culture fish as well as its more rapid expansion the above problems should be solved as far as possible.

\section{References}

BBS. 2011. Statistical Year Book of Bangladesh. Bangladesh Bureau of Statistics, Statistics Division, Ministry of Planning, Government of the People's Republic of Bangladesh, Dhaka. pp.1-533.

Dillon, J.L. and Hardaker, J.B. 1993. Farm Management Research for Small Farmer Development: FAO Farm Systems Management Series 06. FAO Rome. pp. 1-268.

DoF. 2009.). Annul Report. Department of Fisheries, Ministry of Fisheries and Livestock, Government of the People's Republic of Bangladesh, Dhaka. pp. 1-42.

Islam, S. 2010. "Status on Pond Fish Farming and Livelihoods of Rural Fish Farmers in Some Selected Areas of Maulavibazar District. M.S Thesis, Department of Fisheries Management, Bangladesh Agricultural University, Mymensingh. pp. 1- 120. 